\title{
PANOPTICISM OF NORMAL BODY DISCOURSE IN ADVERTISEMENT
}

\author{
Sari Monik Agustin \\ Universitas Indonesia \\ sarimonikagustin@gmail.com
}

\begin{abstract}
This writing aimed to identify panopticism of normal body discourse to advertisement audiences. In addition, this study also aimed to identify the truth game of the normal body discourse in the media. There are some key concepts used as frameworks, particularly Michel Foucault's panopticism, discipline of bodies, power relations and discourse relations. It also used a framework of advertisement in critical perspectives and the philosophy of bodies to enrich the analysis. The paradigm of this writing was critical constructionism. This was a descriptive qualitative research and the data collection techniques were depth interviews with obese women based on BMI standards. This study identified Patriarchy Panopticism, a game of truth of normal body discourse, and the discourse of normal healthy body in media, especially in advertisement as the results. Patriarchy panopticism occurs when discourse and discipline resides invisibly, without coercion and productively maintain the discourse through self-surveillance. At the end, media is only a way to enlarge of Patriarchy Panopticism and used to perpetuate the ideology of patriarchy in the society.
\end{abstract}

Keywords: panopticism, patriarchy, discourse, truth-game, power, advertisement 


\section{INTRODUCTION}

This study departs from the reality of the differences between men and women in society, particularly associated with the body. There are some phenomena in society that shows that women pay more attention to their physical appearance than men. This community perspective and lead to differences in the treatment of community members who have a different appearance than is considered normal, one of which is fat. Obesity is often considered a social problem that leads to stereotypes, labeling, and discrimination. This discrimination arises because of the assumption that fat people are "not normal". And because it is a social problem, fatness is wrong. Hence, fat people must face of being labelled as "abnormal" people.

The discrimination and label to fat people as an abnormal has been related to their capability in society. Fat people often take the blame because of their body and assume of being lazy and self-careless (Watson, deBortali-Tregerthan \& Frank, 1984). People also tend to judge fat people as self-spoiled and lazy. Meanwhile Brehm (1999) said the slim one seen as well-organised and disciplined person (Melliana, 2006). According to Orbach (1993), slimness is seen as a desirable attribute for women in prosperous Western cultures, and is associated with self-control, elegance, social attractiveness, and youth (Grogan, 1999).

Early research in physical attraction often took females as its subjects while male attractions were considering as uninteresting subjects to come up with. These kind of research showed bias as if women appearances were much more interesting and important to be discussed than men's.

Appearance is the only accurate characteristic in predicting satisfaction degree for male and female, but significantly related to appearance accomplishment in women than men. It means beauty is much more significant in perception of femininity than masculinity (Melliana, 2006). Even though appearances take an important part for male and female, generally beauty is defined as a feminine attribute, and appearances' preoccupation is put as part of feminine stereotype.

Labels and stereotypes of fat people is actually can not be generalized, because it turns out there is a difference between the stereotypes of obese men and obese women. Fat women are the focus of this research. Society tend to increase demand on women's appearance. It became a social-control form, which affect how a woman look at herself and how she's looked by others. Social background was the most influencing factor for women in looking of her appearances.

Dissatisfaction over body image has become a common thing for women and sparked concern over weight and dieting behavior. Emphasis assessment of physical appearance of women lies in the physical proportional, such as the size and shape of the body. Women 
with ideal body, or slim, will be getting respect than overweight women. Women with a body fat will be "eliminated". And it was not fun, cause women should strive to stay slim. Mass media, such as commercials and advertisement, TV program, radio, and alike had their own part on this issue. The images on media shows "slim" body type was very dominating, and that positive social assumption is always associated with slimness. On the contrary, negative social perception linked to obesity. Women are told that they can be loved only if they are slim, due to the slimness equated with beauty and also sexually desirable. It seems like there is apparently a "transparent link" between slimming body and beauty and also a fact that slimming body was sexually wanted. Thus, the obese/fat is equal with ugly and unerotic/unsensual, or unsexy (Melliana, 2006).To avoid this, the rise of diet products that claim their products help women avoid obesity without having an eating disorder. This needs to be campaigned extensively because obesity is something that is considered "wrong".

Obesity as a "wrong" discourse becomes mainstream thinking and perpetuated by academics, health practitioners and the media, and it needed a mechanism that will powerfully keep the discourse in the society.

The main hypothesis of this study is that there is a panoptic discipline occurs in society as a mechanism. The big issue lies on how panopticism on normal body discourse in advertisement.

\section{LITERATURE REVIEW}

This study is based on Foucault frameworks on Truth Game, The Power, Knowledge and Discourse, Discipline Body, and Panopticism itself. Thoughts on gender will also be used as researchers saw that this would not be released from the dominant gender ideology prevailing in a society.

Foucault's works actually based on his study of truth. His biggest contribution which lied on his study objects, such as mental institutions, clinic, or prisons, had converted the focus of domination study from Marx's and Marxian's class analysis and economy based (Beilharz, 2003). Foucault exchanged philosophy's intention, not to discovering the real truth (as Plato said, "philosophy is pursuing the truth by all means") or inquiring the relation between truth and things, but to perceive how discourse (philosophy and science) of medical science, madness, prison or sex was shaped and appeared as the truth (Foucault, 1997).

Foucault concerned on how power was applied in knowledge and truth and how the truth was formed through practices in society. His interest of truth was not in abstract or philosophy, but more to analyze what he called as the truth games or the games of truth (Allan, 2006). The word "games" did not mean the truth we saw in history earlier as false 
or only a language construction. Something defined as "false" when "true" had been assumed previously. Due to it, Foucault examined how the truth assumed. The truth mentioned in the truth games, includes rules, sources and practices in "the truth of human creation".

Foucault used counter history as his method. He did not write about history, but spotting other option to see history. History usually seen as sequence of events that were assured as the truth. Foucault refused the proposition for the reason that there was a consequence as discontinuity in history presumed as raw material which had to be constructed, cut or even eliminated to create the continuity. In Foucault's archaeology analysis, discontinuity should not be vanished, but explain clearly. Habermas pointed that Foucault concerned on discontinuity to end global histography, which conceptualize history as macro consciousness (showed up in concepts such as development, reconciliation, evolution, etc) (Hardiyanta, 2002).

It is common that power usually acknowledge as something possessed. In Foucault's mind, power was not possessed, but practicing in dynamic and strategically connecting position field. Though power usually related to person, institution, or state, Foucault pointed the power strategy spread over (Berthens, 1996). It was not possessed, but being part of relations. There were three natures of a relation: communicative, objective, and power. Communication aimed to meaning production, objective means to control and transform, for instance; sains or economy, and power practice, Foucault defined as a group of acts to other acts which aim to control human's act and subjectivity. Power stayed in those acts, not in one's authority or social structure (Berthens, 1996).

Foucault mentioned that power strategy had not been negative, but positively spread over. Power strategy occurred in strategies, networks, mechanisms, techniques which made a decision normally accepted and established (Kritzman, 1988). It spread over and perpetualized by discourses. Power works through formations, rules, or regulation systems in human relationship. Every society knows several truth discourse strategies. Some discourses accepted and distributed as the truth. There are institutions pledging the difference between truth and untruth. There are regulations and procedures to have and distribute the truth (Berthens, 1996).

As mention earlier, power and truth were formed through practices in society. These practices created reality and behavior patterns produce knowledge region, rituals as unique truth. Practices created norms which reproduced and legitimated by teachers, social workers, doctors, judges, administrators, etc, which representing knowledge. So power appears in knowledge, but on the other hand knowledge also produced power. There is no knowledge without power and there is no power without knowledge (Setyadi, 2007). 
The main point is Foucault defined power differently from earlier social giants. He made us see power in knowledge. In the discussion of power and knowledge, Marx mentioned about ideology and false consciousness. According to Weber, knowledge is used as power in bureaucratic society. In Foucault's mind, power was invisible. It's found in truth and discourse, continuously appeared and occurred in body, mind and subjectivity (Allan, 2006).

Panopticism is offered by Foucault, using the analogy of Bentham's prison. According to Foucault, panoptic system is a system in which power relations become total and not physical. Panoptic transformed into another form of supervision, is not accompanied by physical violence on the body. It is a hidden system as power goes, can not be owned, commonly accepted, and beyond recognition, except from the consequences, of the perceived supervision, examination and enforcement of discipline run. In ordinary term, panopticism is similar to self-surveillance. A self is disciplined their own body to obey the main discourse that is accepted as the truth in society. Based on these explanations, basically quite difficult to identify panopticisme in this research. To get a deeper understanding of the intended Foucault's panopticism, then Foucault's thinking about truth, power and knowledge are inseparable. It should be understood that in the perspective of Foucault, power is not possessed but rather scattered.

\section{METHOD}

The paradigm used was critical constructionism. The type of research in this study is descriptive. Descriptive research presents a picture of the specific details of a situation, social setting, or relationship. The goals of descriptive research are: provide an accurate profile of a group, describe a process, mechanism, or relationship, give a verbal or numerical picture, find information to stimulate new explanations, present basic background information or a context, create a set of categories or classify types, clarify a sequence, set of stages, or steps, document information that contradicts prior beliefs about a subject (Neuman, 1997). The data collection techniques were depth-interviews with obese women informants based on BMI standards as a benchmark.

\section{RESULTS AND DISCUSSION}

This study successfully identified several areas that appear in the game truth contestation in the public discourse of the body, among other things:

1. Discourse of the Normal Body is Healthy,

2. Discourse of the Normal Body is Social Normative, and

3. Discourse of the Normal Body is Fashionable.

How is Panopticism of Normal Body Discourse in advertisement? 
Researchers found that the silver line of this study is essentially gender. Gender related to normal body discourse, when women feel normal appropriate to their gender, one is to have a body that is in the category of female normal body.

Normalization of the female body is believed to be the patriarchal domination of women through their body, so the body other than the eye pleasing men would be considered as rebellion. Therefore, patriarchy must work smoothly so as not to blame for the normal body discourse. The trick is to continuously blow this normal body discourse through institutions which perpetuate the values in the society. This is where the hegemony of patriarchal ideology play a role.

Researchers saw that the normalization of women, especially the shape of her body aimed to perpetuate gender inequality. It worked in the interaction and the practice of everyday life, the value of socialization in family and friends, as well as in media content. One of them works in gender stereotypes. Some say that being a female alone is abnormal in a patriarchal world, not to mention becoming obese women. Gender inequality eventually led to what is referred to as the gender hierarchy.

Panopticism is offered by Foucault, using the analogy of Bentham's prison. According to Foucault, panoptic system is a system in which power relations become total and not physical. Panoptic transformed into another form of supervision, is not accompanied by physical violence on the body. It is a hidden system as power goes, can not be owned, commonly accepted, and beyond recognition, except from the consequences, of the perceived supervision, examination and enforcement of discipline run. Based on these explanations, basically quite difficult to identify panopticisme in this research.

To get a deeper understanding of the intended Foucault's panopticism, then Foucault's thinking about truth, power and knowledge are inseparable. It should be understood that in the perspective of Foucault, power is not possessed but rather scattered. In my understanding, the normal body discourse is the dominant discourse in society and it accepted as the truth. Therefore, when the normal body discourse, has been regarded as the truth, then comes a variety of mechanisms and institutions that serve to distinguish between right and wrong.

In this study, the institutions which is taking the role are family, school, friends and media. While the mechanism is found in variety of forms, such as ridicule, advice, prohibition, suggestion, discrimination, etc. Procedures found in this study also appeared in a variety of ways, such as body mass index calculation, the determination of the normal number of health indicators, such as the number of cholesterol, blood pressure, blood sugar, and others. Not only manifests on health knowledge, but also on knowledge of clothing, such as the size of the clothes that are considered normal, and the body is considered to be comfortable and fit with the view of "social eyes". This discourse, according to the findings of researchers, is accepted and circulated as true. True according to what? True 
in accordance with the existing hegemony of patriarchal ideology. It means, the ideology of patriarchy then playing power strategy to be irreversible in the society.

Foucault also mentioned that knowledge relates to power. Researchers found that health knowledge is absolutely accepted as the truth by the informants. Health knowledge has been institutionalized as a power. Why? because health knowledge has forced individuals to do certain things. By using knowledge of health, then a nutritionist seems like having "power" to force informants to attend regularly and on a diet as suggested. Through this knowledge also, the power strategy played by the parents to govern their children to follow the rules of health practices, and others. This power, not to be negative, but productive. It does not work through oppression and repressive, but through normalization and regulation and are considered to be positive even by individuals themselves. Normalization is a power strategy. This research found that normalization of the body existed through the practices and the power strategies, especially the practices to follow the norms established to the body that is considered right by society. The symbol of this is the body weight.

This study found that ads have contributions to control people's behavior, so that the physical body is no longer required to follow the normal body's power, but also the mind, consciousness and the individual's will. For example, some informants stated that they do not care about the normal body discourse, do not want to slim down and do not care about body fat. However, informants also maintained that she was aware that she was breaking the rules and feel guilty about it. It shows that the informants'consciousness and the mind has determined that normal body discourse is the truth, so when she becomes different, it's wrong. Another informant, for example, stated that because an ad featuring her idol, then she wanted to have the body and style as displayed by the models she adores. It shows that the thoughts and desires then helped set up the physical body to constantly be in the right corridor desired by patriarchal ideology.

This led to an awareness of Foucault's thoughts on the body discipline. The body discipline in practice related to panopticism, where in the panopticism appear on power relations of the normal body discourse. In this discussion, the researcher offers the concept of patriarchy panopticism, which means there are activities or a system to perpetuate patriarchal ideology. The parties who perform the panoptic role are institutions which participated to perpetuate the ideology.

By using this system, one time control over the normal body discourse is sufficiently done, but the effect is continuous. This is essentially intended for other things outside the body, but what happens is, the informants of this study actually given up due to body issues and real consequences. Thus, any informants' experiences, which reminded them of the women's bodies normal discourse can be categorized as panopticism. 
According to Foucault, panoptic system is a system in which power relations become total and not physical. Take for example one of the informants, was always remember about Impressions Body Care Center print ads that she saw when she was a teenager, about 10 to 15 years ago. The ad itself no longer can be explained in detail, but the normal body discourse was still remembered. She even still wanted to try and keep bringing that desire.

Several other informants, for example, remembered a piece of slimming product on TV commercial. Some of them could not name the product being advertised, but they clearly remember the ad and know that the scenes in the ad are a suggestion to keep the body in order to stay in the society desired condition as a normal body, the slim body. One informant said that when she remembered the advertisement scene, even though the ad is no longer visible in front of her eyes, she still felt guilty when eating food which is forbiden due to the needs of the body to be slim.

Other findings indicate that temporary advertisement display was able to be remembered by the informants, not the product, but on the issue. Ads that was just serves as a reminder, now serves more deeply, which is panoptic. This is what is referred to as panopticism. Advertisement is no longer just a reminder, but also master the individual to remain always remember and act in harmony with the public wants, which behave according to the rules of a normal body discourse.

This proves that although the presence of the display media about the normal body discourse is only temporary, the normal body discourse still haunts the informants. That means, when the informant be disciplined to follow the normal body discourse, then panopticism happen. From these explanations, it can be concluded that there is a power that is no longer physical, which then seemed to force it to stay abreast of and discipline in the normal women's bodies discourse that have been established in the society.

\section{CONCLUSSION}

The conclusion is, this study had successfully identified Patriarchy Panopticism, a game of truth of normal body discourse, and the normal and healthy body discourse in media, especially in advertisement. Patriarchy panopticism occurs when discourse and discipline resides invisibly, without coercion and productively maintain the discourse through self-surveillance. As a result, media is only a way to enlarge of Patriarchy Panopticism and used to perpetuate the ideology of patriarchy in the society. 


\section{REFERENCES}

Adelman, Miriam \& Lennita Ruggi. (2008). "The Beautiful and The Abject: Gender, Identity and Constructions of the Body in Contemporary Brazillian Culture" dalam Current Sociology, vol 56, no. 4, Monograph 2, Journal of the International Sociological Association, July 2008.

Agustin, Sari Monik. (2009). Foucault dan Komunikasi: Telaah Konstruksi Wacana dan Kuasa Foucault dalam Lingkup Ilmu Komunikasi. Yogyakarta: Jurnal Ilmu Komunikasi UPN “Veteran” Yogyakarta (terakreditasi B).

Agustin, Sari Monik. (2009). Konstruksi Wacana Tubuh Normatif pada Konsep Diri Perempuan Lajang Gemuk Dewasa di Jakarta. Universitas Indonesia: Jurnal Thesis Vol 7 No 3, Sept - Des 2009.

Allan, Kenneth. (2006). Contemporary Social and Sociological Theory. California: Pine Forge Press, Sage Publications, Inc.

Beilharz, Peter. 2003. Teori-teori Sosial. Yogyakarta: Pustaka Pelajar.

Bentham, Jeremy. (1995). The Panopticon Writings. Ed. Miran Bozovic. London: Verso.

Berthens, K. (1996). Seri Filsafat Atmajaya: Filsafat Barat Abad XX jiid II: PRANCIS. Jakarta: PT Gramedia Pustaka Utama.

Blood, Sylvia. (2005). Body Work. London \& NY: Routledge

Cook, Guy. (2001). The Discourse of Advertising. USA: Routledge

Coser, Lewis A.. (1977). Masters of Sociological Thought. 2nd ed. USA: Harcourt Brace Jovanovich, Inc.

Daoren. (2006). "Orang Gemuk Lebih Gampang Depresi", dalam http://community.siutao.com/archive/index.php/t-1794.html, 7 agustus 2006, 21:51, diakses 10/03/2012, pkl 06.25

Depkes RI. (2009). Obesitas dan Kurang Aktivitas Fisik Menyumbang 30\% Kanker, dalam http://www.depkes.go.id/index.php/berita/press-release/137-obesitas-dankurang-aktivitas-fisik-menyumbang-30-kanker.pdf diakses 15/06/2013 pkl 23.55

Dubrofsky, Rachel E. (2011). Surveillance on Reality Television and Facebook: From Authenticity to Flowing Data dalam Communication Theory. ISSN 1050-3293, 111 129. DOI 10.1111/j. 1468-2885.2011.01378.x, USA: International Communication Association

Dyer, Gillian. (1982). Advertising as Communication. London: Routledge

Febrida, Melly. (2012). Pernikahan bisa membuat Wanita bertambah Gemuk, dalam http://health.liputan6.com/read/456921/pernikahan-bisa-membuat-wanitabertambah-gemuk 21 November 2012, diakses 15/06/2013, pkl 12.02 
Foucault, Michel. (1972). The Archaeology of Knowledge (Translation). London: Tavistock Publications Limited

Foucault, Michel. (1978). History of Sexuality, Volume 1: An Introduction. New York: Pantheon Books

Foucault, Michel. (1995). Discipline and Punish, The Birth of the Prison. Translated by Alan Sheridan. New York: Vintage Books

Foucault, Michel. (1997). Seks dan Kekuasaan. Jakarta: PT Gramedia Pustaka Utama.

Foucault, Michel. (2007). The Politics of Truth. Los Angeles: Semiotext(e)

Gordon, Colin (ed). (1980). Michel Foucault: Power/Knowledge (Selected Interviews and Other Writings, 1972 - 1977). Great Britain: The Harvester Press

Gramsci, Antonio. (1971). Selections from The Prison Notebooks. New York : International Publishers.

Grogan, Sarah. (1999). Body Image. London \& NY: Routledge

Gros, Frederic, ed. (2011). Michel Foucault: The Courage of the Truth (The Government of Self and Others II), Lectures at The College de France 1983-1984. UK: Palgrave Macmillan

Hackley, Christopher. (2002). The Panoptic Role of Advertising Agencies in the Production of Consumer Culture. In Consumption, Markets and Culture, 5/3, 211-229 D0I: 10.1080/10253860290031640 (reprinted in Chris Hackley (Ed) Advertising (2009) Vol 2 Advertising Culture, London, Sage, pp 363-388.

Hardiyanta, Petrus Sunu. (1997). Michel Foucault, Disiplin Tubuh, Bengkel Individu Modern. Yogyakarta: LkiS Yogyakarta.

Harian Neraca. (2012). Peningkatan Jumlah Obesitas di Indonesia, dalam http://www.neraca.co.id/harian/article/18956/Peningkatan.Jumlah.Obesitas.di.I ndonesia 22 September 2012, diakses 15/06/2013, pkl 13.59

Hartley, John. (2004). Communication, Cultural, and Media Studies: Konsep Kunci. Yogyakarta: Jalasutra.

Haryatmoko. (2012). Kekuasaan Melahirkan Anti-Kekuasaan. Jakarta: Majalah BASIS edisi Mei-Juni 2002

Hasinoff, Amy Adele. (2012). Book Review of "The Surveillance of Women on Reality Television: Watching The Bachelor and The Bachelorette" dalam Jurnal Popular Communication, Vol 10. No. 3, Juli - September. USA: Routledge.

Hay. (2011). Xtra-L Community: Memupuk Rasa Percaya Diri Mereka yang Ekstrabesar, dalam http://koran-jakarta.com/index.php/detail/view01/72790 diakses Sabtu, 22/06/2013, pkl 07.26 
Kritzman, Lawrence D., ed. (1988). Michel Foucault. Politics, Philosophy, Culture, Interviews and Other Writings 1977 - 1984. New York: Routledge

Kurniasari, Triwik. (2010). Big is The New Slim, dalam http://www.thejakartapost.com/news/2010/03/28/big-new-slim.html diakses 22/6/13, pkl 07.30

Melliana S, Annastasia. (2006). Menjelajah Tubuh: Perempuan dan Mitos Kecantikan,. Yogyakarta: LkiS.

Mills, Sara. (2004). Discourse. USA: Routledge

Mona, Leila. (2012). Nyarbod: Studi tentang Disiplin Tubuh dalam Pendidikan Karakter di Sekolah Islam Berasrama. Tesis. Depok: Universitas Indonesia

Muwarni, Endah. (2009). Iklan sebagai Kekerasan Simbolik: Studi tentang Relasi HabitusField dalam Produksi dan Konsumsi Image Simbolik Tubuh Sehat. Disertasi. Depok: Universitas Indonesia

Neuman, W. Lawrence. (2003). Social Research Methods: Qualitative and Quantitative Approaches 5th Edition. USA: Pearson Education

Neuman, W. Lawrence. (2011). Social Research Methods: Qualitative and Quantitative Approaches 7th Edition. USA: Pearson Education

Nutricia. (2013). Bila dibiarkan, Kegemukan dan Obesitas akan menjadi Epidemi di Indonesia, dalam http://nutricia.co.id/bila-dibiarkan-kegemukan-dan-obesitasakan-menjadi-epidemi-di-indonesia/ 12 Juni 2013, diakses 15/06/2013, pkl 16.53

O’Farrell, Clare. (2005). Michel Foucault. London: Sage Publications

Pangkahila, Wimpie, Prof. Dr. dr., sp. And. (2005). "Seks Orang Gemuk”, KOMPAS Cyber Media, Kamis, 8 Desember 2005, 12:12 WIB, diakses 10/03/2012, pkl 06.10

Patton, Michael Quinn. (2002). Qualitative Research and Evaluation Methods, 3rd Edition. California: Sage Publication

Pitakasari, Ajeng Ritzki. (2011). Perempuan Tambah Gemuk Setelah Menikah? Mungkin Ini Alasannya, dalam http://www.republika.co.id/berita/humaira/ibuanak/13/06/07/mnz0p1-setelah-menikah-jadi-gemuk-mungkin-ini-alasannya 16 Desember 2011, diakses 15/06/2013, pkl 11.39

Sahabat Sehat. (2013). Cara Menghitung Berat Badan Ideal Dengan Tepat, dalam http://www.sahabatsehat.info/2012/10/cara-menghitung-berat-badanideal.html diakses 23/5/2014, pkl. 13.14

Sartika, Ratu Ayu Dewi. (2011). Faktor Risiko Obesitas pada anak 5-15 Tahun di Indonesia. Depok: Jurnal Makara, Kesehatan, Vol 15. No 1. Juni 2011. 
Setyadi, Wawan. (2007). Kebenaran dan Kekuasaan: Menelanjangi Kedok Kebenaran A la Michel Foucault in DRIYARKARA, Jurnal Filsafat. Th. XXIX no 2 / 2007. Diskursus Tentang Kebenaran. Jakarta: STF Driyarkara.

Sugiharto, I. Bambang. (2000). “Penjara Jiwa, Mesin Hasrat: Tubuh Sepanjang Budaya”, dalam Menguak Tubuh. Jurnal Kebudayaan KALAM no. 15. Jakarta: Komunitas Utan Kayu

Sunarto, Kamanto. (2009). Sosiologi Kesehatan. Jakarta: Penerbit Universitas Terbuka.

Susi. (2012). Komunitas Besar Indonesia (KOMBES Indonesia): "The Power of BIG", dalam http://www.tnol.co.id/komunitas/minat/17238-komunitas-besarindonesia-kombes-indonesia-qthe-power-of-bigq.html diakses 23/06/2013, pkl. 14.40

Suter, W. Newton. (2012). Introduction to Educational Research: A Critical Thinking Approach, Second Edition. USA: Sage Publications

Syafputri, Ella. (2012). 27 Juta Penduduk Indonesia Alami Obesitas, dalam http://www.antaranews.com/berita/319738/27-juta-penduduk-indonesia-alamiobesitas 4 Juli 2012, diakses 15/06/2013, pkl 14.19

Synnott, Anthony. (2003). Tubuh Sosial : Simbolisme, Diri, dan Masyarakat. Yogyakarta: Jalasutra

Tomagola, Tamrin Amal. (1990). Indonesian Women's Magazine as an Ideological Medium. Disertasi. Depok: FISIP Universitas Indonesia

Turner, Bryan S. (1992). Regulating Body. London \& NY: Routledge

Turow, Joseph dan Matthew P. Mcallister. (2009). The Advertising and Consumer Culture Reader. New York: Routledge.

Wolf, Michele A., Sandy Nichols, David F. Decelle. (1997). Mass Media, Body, Self: How Women of Different Sexual Orientations Relates to Mass Media's Construction of Body. Paper presented at the ANnual Meeting of the Western States Communication Association, February 1997, Monterey, CA 